\title{
Dediščina prve svetovne vojne: reprezentacije in reinterpretacije
}

Jurij Fikfak in Božidar Jezernik

Med letoma 2014 in 2018 se je v Evropi zgodilo veliko dogodkov v povezavi s stotimi obletnicami prve svetovne vojne: najprej obletnica njenega začetka $\mathrm{z}$ atentatom $\mathrm{v}$ Sarajevu, ki so se je tako v samem mestu kot drugje spomnili leta 2014 in je bila za številne predmet spora; obletnica vstopa Italije v vojno na angleški in francoski strani, ki so jo obeležili leta 2015 in jo je, na primer, v Gorici/Gorizii zaznamovala dinamika manifestacije neofašističnega gibanja CasaPound na eni in nasprotnikov na drugi strani; ob obletnici vstopa ZDA v vojno v letu 2017 in na slovenskih tleh z rekonstrukcijo 12. soške ofenzive, $s$ katero so oktobra 2017 avstro-ogrske vojaške sile pregnale italijansko vojsko vse do Piave; in nazadnje s stoletnico konca vojne leta 2018.

A o tem, na katere informacije o dogodkih, praksah spominjanja bomo naleteli, je zlasti odvisno od tega, v kateri državi ali regiji iščemo določen podatek ali definicijo; odvisno je tudi od tega, ali je 
uporabljeni iskalni niz »vélika vojna « ali »prva svetovna vojna «. Tako je $\mathrm{v}$ angleško govorečem kontekstu navadno za začetek vojne navadno izhodišče Balkan, imenovan tudi »evropski sod smodnika «, na spletnih straneh zahoda pa je glavni poudarek na zahodni fronti ter britanskih in francoskih žrtvah. Kot pravi John Schindler (2001), so največkrat zapostavljene fronte na vzhodu, med njimi še posebej soška ali kot pišejo v Italiji in drugje italijanska fronta. Seveda je treba opozoriti na dejstvo, da so se na evropskem zahodu najprej začele obsežnejše in sistematične aktivnosti, na primer komemoracije, takoj po vojni so že postavljali cerkve in spomenike (denimo v Ypresu).

Vsi ti posamezni, naključno izbrani primeri pričajo o tem, da sta prva svetovna vojna in njena dediščina predmet nenehnih diskurzov, ambivalentni predmet nesoglasij in sporov; $\mathrm{v}$ zadnjem času, še posebej z intenzivnimi aktivnostmi v okviru Evropske unije, pa je moč razbrati, da lahko posamezni dogodki kot tudi lokacije postanejo mesto srečanja in spravnih slovesnosti. Tako se je leta 1984 med Françoisem Mitterrandom in Helmutom Kohlom zgodila ena prvih spominskih in simbolično spravnih slovesnosti na mestu bitke pri Verdunu, kjer je bilo ubitih okoli 300.000 vojakov na obeh straneh (gl. Bajuk Senčar v tej knjigi). Slovenski predsednik Danilo Türk in italijanski Giorgio Napolitano sta bila pokrovitelja Poti miru, poti, ki poteka po območju soške fronte; leta 2016 pa sta slovenski predsednik Borut Pahor in italijanski Sergio Mattarella odkrila spomenik slovenskim vojakom na Doberdobski planoti.

Ko razmišljamo o dediščini ali dediščinah prve svetovne vojne, je moč govoriti o zelo različnih motivih, težnjah, praksah kot tudi različnih kontekstih, v katerih se vzpostavlja, uporablja, razvija in osmišlja, a tudi zapostavlja ali celo uničuje. V našem knjižnem premisleku o dediščini in dediščinah prve svetovne vojne tako načenjamo nekatere procese dediščinjenja, produkcijo in spremembo dediščinskega statusa objektov, spomenikov, spomeniških parkov ali krajin ter jih prevprašujemo tudi s pogledi Roberta Hewisona (1987) in Kevina Walsha (1992). Prav tako obravnavamo tudi dediščinsko razvojne usmeritve, predvsem v turizmu in kontekstu komemoracije 100-letnice vélike vojne. Regina Bendix meni, da koncept dediščine predpostavlja razmerje, sestavljeno iz pravic in odgovornosti skupnosti do elementov dediščine (Bendix 2009). Gre za raziskavo različnih vrst razmerij, ki jih ustvarja produkcija spomenikov oziroma spomeniških objektov, hkrati pa namenja pozornost različnim družbenim skupinam in ciljnim publikam na lokalni, regionalni, nacionalni ali evropski/globalni ravni.

Prva svetovna vojna je bila prva vojna, v kateri je vojaška industrija demonstrirala svoje možnosti in sposobnosti za produkcijo 
sredstev za uničevanje. Posledice so bile strahotne: več kot 16 milijonov mrtvih, od tega približno 10 milijonov vojakov in nad 6 milijonov civilistov (Prost 2014). Visok krvni davek so plačale tudi številne slovenske družine, saj je od okoli 160.000 slovenskih vojakov na bojiščih za vedno obležalo okoli 35.000 , medtem ko je morijo preživelo nad 11.000 vojnih invalidov. Življenje z milijoni mrtvih in pohabljenih je terjalo temeljite spremembe na vseh področjih življenja, sledilo je prevrednotenje nekdanjih vrednot; te spremembe so vplivale in oblikovale nove načine kot tudi vsebine spominjanja, zavesti in skupinskih oziroma skupnostnih pripadnosti.

Vélika vojna je temeljito spremenila življenje ljudi; tako je množična mobilizacija tesno zbližala pripadnike različnih družbenih plasti, prej ločenih $\mathrm{z}$ visokimi zidovi stanovskih in razrednih razlik. $V$ bojnih rovih je demokratizacija družbenega življenja postala realnost, postala je družbeno dejstvo po vseh državah udeleženkah. Vplivala oz. spremenila je razmerje med spoloma. Odsotnost okoli 60 milijonov moških zaradi odhoda na bojišča je ženskam odprla pot do družbenih vlog in položajev, ki so bili prej rezervirani le za moške. Najbolj krvava vojna v zgodovini je imela za posledico tudi razpad treh starodavnih imperijev: avstrijskega, otomanskega in ruskega; nadomestile so jih nove nacionalne države, med njimi je bila tudi Kraljevina Srbov, Hrvatov in Slovencev, ki je prvič povezala v eno skupnost večino južnih Slovanov.

George Mosse, Jay Winter in drugi raziskovalci vélike vojne in spominjanja nanjo ugotavljajo, da je ogromno število žrtev povzročilo velikanski preobrat v javnem spominu. Če so bili prej heroji, katerih slavna dela so hoteli okameniti v spominu za prihodnje generacije, vojskovodje, medtem ko so bili navadni vojaki prepuščeni pozabi, so po letu 1918 tradicionalne junake kolektivnega spomina sčasoma zamenjali $\gg$ neznani vojaki«, to je »vojaki prostaki«, ki so nosili največji del teže in nevarnosti »najtežje vojne «. Strahotna bilanca vojne, ki ni imela primere niti v izkušnji sodobnikov niti v zgodovinskih kronikah, je odprla in ugladila pot demokratični misli. Spremembo v kolektivnem spominu najizraziteje ilustrira spomenik v mestu Metz na francosko-nemški meji. Po francosko-pruski vojni leta 1871 je mesto pripadlo Nemčiji, in postavili so spomenik nemškemu cesarju Wilhelmu II. Po prvi vojni je mesto spet pripadlo Franciji, spomenik so podrli, namesto njega pa postavili spomenik francoskemu poiluju, to je navadnemu vojaku.

Prva svetovna vojna je kot eno najbolj tragičnih obdobij v zgodovini dvajsetega stoletja v Evropi za seboj pustila neizbrisen spomin, ki se je od vojne pa vse do danes manifestiral na najrazličnejše načine: $\mathrm{v}$ osebnih spominih, dnevnikih in drugih zapisih udeležencev vojne 


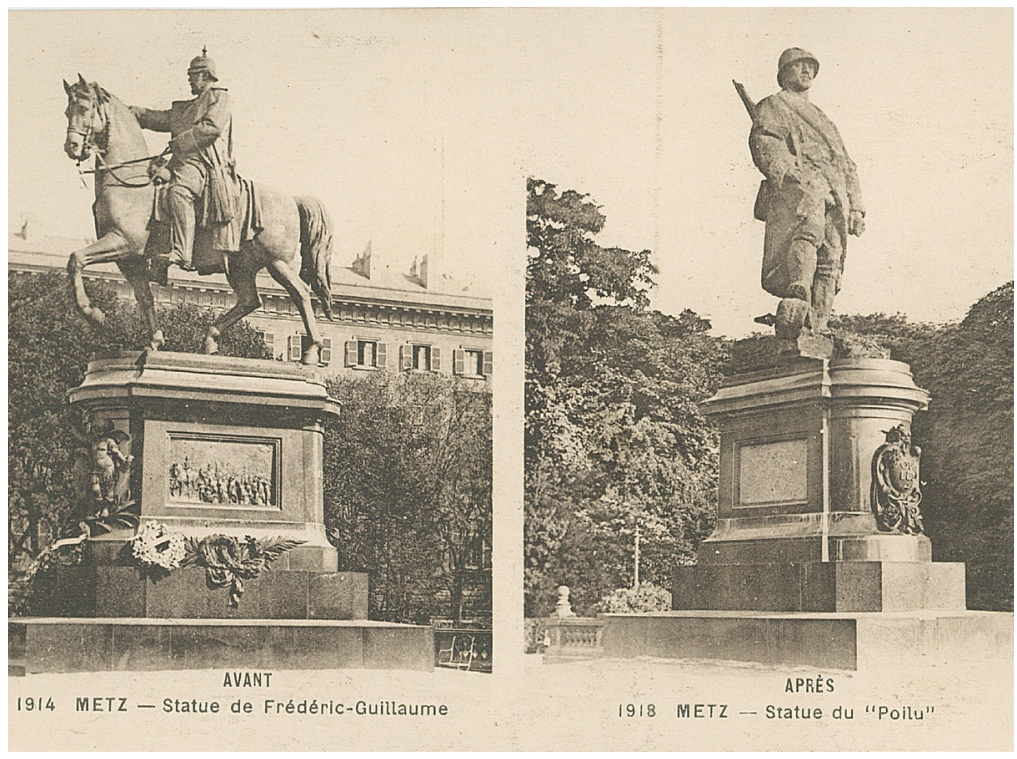

Slika 1: Metz leta 1914 (spomenik pruskemu cesarju) in leta 1918 (spomenik francoskemu vojaku-prostaku) (razglednica iz zbirke Božidarja Jezernika)

in oddaljenih opazovalcev, $\mathrm{v}$ javnih spomenikih in muzejih, naracijah zgodovinopisja in drugih opisovalcev preteklih dogodkov, $\mathrm{v}$ spremenjeni pokrajini in, ne nazadnje, tudi v glasbi in umetnosti. To obdobje in spomini nanj so bili v humanistiki že ničkolikokrat preučeni; stoletnice so bile še poseben motiv za raziskovanja in seznanjanja, a so kljub temu ostale bele lise neznanja. Prvi temeljitejši pregledi so objavljeni šele v Enciklopediji prve svetovne vojne (npr. Manojlović Pintar 2014; Šarenac 2014; Svoljšak 2018).

Knjiga tako temelji na posameznih raziskavah, ki z uporabo arhivske, diskurzivne in etnografske metode analizirajo tako zgodovinske kot sodobne oblike spominjanja na véliko vojno, relacije med njimi in genealogijo spominov, torej spreminjanje spominskih krajin od vojne do današnjih dni, ko je ob stoletnici vojne organiziranje spominjanja postalo še posebej izrazito. Gre za preučevanje specifičnosti produkcije in ohranjanja spomina na véliko vojno v slovenskem delu Kraljevine SHS ter deželah Kraljevine Italije in Republike Avstrije s slovenskim prebivalstvom. Pri tem so zagotovo zanimive in povedne razlike v spominu na véliko vojno, ki so bile pogojene $\mathrm{z}$ različnimi položaji posameznih držav, zmagovalk in poraženk, $s$ parcialnostjo in politikami spomina, procesi in strategijami ohranjanja spomina, protislovji in spornostmi spomina. Vélika vojna je bila kot politično bojišče hkrati torišče skupinskih identitet, torej intenziven družbeni proces, 
ki so ga ustvarjale družbene skupine s prekrivajočimi ali divergentnimi interesi in ki mu daje postavljanje spomenikov vidno mesto v družbeni krajini, komemoracije ob njih pa ga napolnjujejo z vsebinami.

Delo je strukturirano po sklopih, ki osvetljujejo različne oblike manifestacij in ustvarjanja spomina: 1. Vojaški grobovi in spomeniki; 2. Komemorativne prakse, spominske slovesnosti in produkcije spomina v sodobnosti; 3 . Sodobne (re)interpretacije prve svetovne vojne.

\section{VOJAŠKI GROBOVI IN SPOMENIKI}

Po končani véliki vojni so se zmagovalci in poraženci zbližali ob počastitvi vojnih grobov ter izkazali spoštovanje in čast padlim vojakom vseh narodnosti, bojišč in bitk. Meddržavni dogovori so državam udeleženkam nalagali, da je treba urediti grobišča vojakov ne glede na njihovo narodno in državno pripadnost. Spomenike padlim so množično postavljali po mestih in vaseh širom evropske celine. Vélika vojna je po besedah Jaya Winterja sprožila »plaz podob in besed, in kult spomina je postal univerzalni fenomen «(Winter 2006). Spomeniki so bili pomnik požrtvovalnosti in trpljenju padlih vojakov; med temi državami je bila ena izjema, Kraljevina SHS, zato so nekateri v zvezi s tem začeli govoriti kot o »sramoti «.

S spomeniki so nastajale spominske krajine, ki so omogočale različna doživljanja, diskurze in tematizacije med eksperti, ustanovami, ljubiteljskimi zbiralci, domačini, obiskovalci. Nekateri objekti, na primer spominska obeležja, pokopališča, mulatjere, so postali kraji spomina.

V Julijskih Alpah so prva spominska obeležja namreč nastala že med samo vojno. V Posočju so leta 1916 vojaki III. gorske brigade avstro-ogrske vojske $\mathrm{v}$ spomin na padle soborce zgradili secesijsko cerkev sv. Duha na Javorci, ki jo je zasnoval dunajski arhitekt Remigius Geyling, vodja del pa je bil Madžar Geza Jablonsky. Ob vhodnih vratih je latinski napis »Sovraštvo naj ne sega prek pepela umrlih «.

V spomin vojaškim ujetnikom iz Rusije, ki jih je na prelazu Vršič leta 1916 zasul plaz, so isto leto zgradili tudi Rusko kapelico, ki je danes pomembna za memorializacijo vélike vojne v Sloveniji. Postala je pomembno stičišče za različne oblike kulturnega in gospodarskega sodelovanja med dvema državama, Slovenijo in Rusijo.

Iz tega časa so tudi številna pokopališča in obeležja padlim vojakom, tako v Posočju kot v vzhodnih Julijskih Alpah. Ker je po vojni območje Posočja pripadlo Italiji, so nastajali spomeniki, ki so obeleževali 
italijanske žrtve, na primer kapela v Gabrju, ki so jo leta 1920 na italijanskem vojaškem pokopališču zgradili vojaki gorskih enot, »alpini«, in na vhodu kapele postavili napis $\gg$ Torneranno $\ll(» \operatorname{Vrnili}$ se bodo $\ll)$.

V Jugoslaviji so bili po letu 1945 številni avstro-ogrski in italijanski spomeniki prepuščeni propadanju in pozabi; kapela v Gabrju je služila kot gospodarski objekt. V času komemoracij ob spomenikih NOB je, na primer, cerkev na Javorci propadala vse do začetka 1980-ih let.

Novo obdobje spominjanja in komemoracij je nastopilo z osamosvojitvijo Slovenije ter odkrivanjem časov in dogodkov pred letoma 1941 in 1945. Različni akterji so začeli obnavljati pozabljene spomenike in postavljati nove. $V$ tem prelomnem času se pojavijo nove tendence $\mathrm{v}$ interpretaciji nacionalne zgodovine oziroma $\mathrm{v}$ nacionalnem spominu. Do 1990 prevladujoča druga svetovna vojna namreč postane zgodovinsko obdobje, ki je »delilo Slovence«, vélika vojna pa čas krvavih in nesmiselnih bojev med narodi. Njen nauk je mir kot » univerzalna « vrednota: simbolizacija te vrednote se zgodi v čezmejno slovensko-italijanskem projektu Pot miru od Alp do Jadrana, ${ }^{1}$ katere pokrovitelja sta bila predsednika držav, slovenski Danilo Türk in italijanski Giorgio Napolitano. K drugačnemu odnosu do spomina in spomenikov so prispevali tudi integracijski procesi v Evropi v 1990-ih letih, ki so spominjanja na strahote in vojne na evropskih tleh dojemali kot opomin in izhodišče za mednarodno sožitje. Največji uspeh pa so lokalne iniciative za obujanje spomina na soško fronto doživele leta 1993, ko je kobariški muzej prve svetovne vojne prejel muzejsko nagrado Sveta Evrope.

Vojaški spomeniki in grobovi so konstitutivni element vojnega socialnega spomina in navidezno skupne različice preteklosti. Gradnja spomenikov in njihov pomen sta se spreminjala, v različnih kronotopih sta izražala nekatere prednostne naloge in vrednote. Tako je Winter (1995) ugotovil, da so bili nekateri spomeniki, postavljeni takoj po vojni, posvečeni padlim svojcem. Pri drugih spomenikih so se spominjali vseh, ki so svoja življenja žrtvovali za narod ali cesarstvo (Mosse 1990; Lloyd 1998; Howard 2003; Winter 2006; Inglis in Brazier 2008). Spomeniki pomembno soustvarjajo diskurze medvojnega družbenega spomina; gre za proces, v katerem se različne družbene skupine pogajajo o spominih in izkušnjah vojne. $\mathrm{V}$ tem procesu so se nekatere izkušnje in reprezentacije (Inglis 1987), utelešene v spomenikih, preprosto pozabile. Dejanja pozabe pa niso le na ravni diskurza in socialnega spomina, veliko je tudi fizičnih izbrisov sledi vojne v krajini 
(Carlyon 2006; Scates 2006). Spominjanje in počastitve v imenu nacije ali imperija navadno zasenčijo resničnost in grozote vojne. $\mathrm{V}$ takojšnjem povojnem spominjanju so ljudje skoraj samoumevno izbrali »čiščenje « pokrajine, zaznamovane z bitkami, tudi tako, da so zgradili pokopališča in spomenike ter nadaljevali gospodarske aktivnosti. Caroline Winter (2009) trdi, da kažejo te strategije na splošno družbeno potrebo po žalovanju in hkrati po zagotovitvi nove normalnosti, to je življenja brez padlih svojcev (Fussell 1977; Mosse 1990; Lloyd 1998; Carlyon 2006; Winter 2006; Inglis 2008).

Po ustanovitvi nacionalne države južnih Slovanov (SHS) so dobile spominske svečanosti ob pomembnih zgodovinskih obletnicah in na prizoriščih zmagovitih bitk srbske vojske in dobrovoljcev državotvorni značaj, spomin na avstro-ogrske vojne žrtve pa je bil potisnjen v pozabo, saj so padle za tujo, v vojni poraženo vojsko (prim. Bokovoy 2001). Na srbski strani so veterani kljub dejstvu, da je bilo njihovih žrtev več, imeli vsaj zadoščenje, da njihovo trpljenje in požrtvovalnost nista bila zaman; dosegli so osvoboditev in »ujedinjenje « Jugoslovanov. Napad avstro-ogrske vojske, poraz, umik, okupacija in na koncu zmaga $v$ vojni proti premočnemu nasprotniku so postali elementi srbske narativne samopodobe o vojni, ki so podeljevali smisel vojnim izkušnjam.

Po vojni so v spomin padlim vojakom širom evropske celine pa tudi drugje po svetu postavili na tisoče spominskih znamenj in spomenikov. Ob odkritjih in pozneje ob jubilejih so sodobniki posameznim spomenikom posvečali izredno pozornost. Rezultat je na tisoče knjig, večinoma posvečenih posameznim spomenikom. Med njimi velja zlasti poudariti dela Georgea Mosseja in Jaya Winterja. Na Slovenskem je bilo največ informacij, posvečenih posameznim spomenikom in spominskim slovesnostim, v dnevnem tisku in v reviji Mladika.

Druga svetovna vojna je te spomenike potisnila v drugi plan ali pozabo. Na Slovenskem je prvi celovitejši pregled slovenskih spomenikov padlim vojakom objavila Špelca Čopič leta 1987. Spomenike in vprašanje njihove vloge pri oblikovanju slovenske identitete v nasprotju z jugoslovansko identiteto je obravnaval Božidar Jezernik v poglavju monografije o javnih spomenikih v Ljubljani (2014). S tematiko se je $\mathrm{v}$ preteklosti in danes ukvarjalo več varstvenih in raziskovalnih ustanov. Spomeniškovarstvena služba je že v 1980-ih letih pripravljala evidence dediščine in zaščitne odloke (na primer občina Ajdovščina leta 1987) za posamezne objekte. Na zahodu in v zaledju soške fronte so bila to vojaška pokopališča, drugje večinoma javni spomeniki $s$ skulpturami znanih umetnikov. Med letoma 2007 in 2008 je Zavod za varstvo kulturne dediščine RS pripravil Strokovne zasnove varstva 
kulturne dediščine, tako da so vpisali vse dediščinsko pomembne lokalitete vélike vojne. Velja opozoriti na spletne projekte, npr. projekt Arzenal na ZRC SAZU - spomeniki 1. svetovne vojne (www.arzenal. si) ali 100letprve.si (http://www.100letprve.si/index.html).

Pomembne so monografije več avtorjev, na primer Vasje Klavore (2004; 2007; 2011), ki je obravnaval tudi spomenike in znamenja, dela Dimitrija Omerse (1998), Damjana Prelovška in Vlasta Kopača (1992) kot tudi tujih avtorjev s področja varstva dediščine (Staniforth 2013; Szczepanowska 2013), varstva dediščine in človekovih pravic (Silverman in Ruggles 2007) ter vključevanja dediščine v turizem ( $\mathrm{Ti}$ mothy 2011), kar je tudi eden od pomembnih izzivov, povezanih z recepcijo dediščine vélike vojne.

V tej monografiji, v zelo obsežni razpravi o spomenikih na Slovenskem Vito Hazler zarisuje stanje in podobo spominskih objektov. Številni spomeniki v spomin na padle vojake imajo svoje reprezentativno vsebinsko ozadje, ki je od primera do primera različno. Nekateri objekti so v neposrednem stiku z vojaškimi pokopališči, nekateri so poleg središčnega križa osrednja dominanta civilnih pokopališč, drugi so sredi vasi, ob glavnih krajevnih cestah, lahko so ohranjeni kot samostojni nagrobniki na pokopališčih ali vstavki v obliki spominskih plošč na zunanjščinah ali v notranjščinah številnih katoliških cerkva. Anja Moric dodaja pregled spominskih obeležij padlim vojakom v prvi svetovni vojni na Kočevskem, področju z visokim deležem prebivalstva, ki je stoletja ohranjalo nemško narodno zavest.

Po koncu vélike vojne si je velik del Evrope zastavljal vprašanje o njenem smislu. Odpirale so ga tudi številne žalne slovesnosti, posvečene spominu padlih vojakov, ki so prva povojna leta po različnih delih celine potekale iz dneva $\mathrm{v}$ dan. $S$ tem vprašanjem so bili tako ali drugače soočeni tudi državljani Kraljevine SHS. Njihovo (samo) spraševanje in iskanje pravih odgovorov nanje pa je dodatno obremenjevalo dejstvo, da so se v véliki vojni tedanji državljani države »troimenega naroda « bojevali kot pripadniki sovražnih vojsk na nasprotnih straneh. Že samo to dejstvo, ugotavlja Božidar Jezernik, je bilo dovolj visoka ovira za dosego soglasnega »uradnega « spomina na vojno. Še večji problem je predstavljalo drugo dejstvo, namreč, da teh vprašanj niso nikoli zares in premišljeno tematizirali, temveč so jih prepustili stihijski mešanici zmagoslavnega (samo)zadovoljstva na eni strani in zmedenega iskanja svoje olepšane podobe na drugi. Ko so po nekaj letih zatišja v Sloveniji in Srbiji - v drugih delih nekdanje skupne države jih tako rekoč ni bilo - začeli postavljati spomenike padlim vojakom, pa je ohranjanje spomina na mrtve kmalu postalo sestavni element nacionalističnih diskurzov. 
Javni spomeniki institucionalizirajo in legitimizirajo spomine, svečanosti ob njihovem odkritju ali komemoracije ob obletnicah pa podčrtujejo vrednotenje preteklosti. Ker je družbeni spomin predvsem odsev sinhronih politično-socialnih razmerij in se spreminja skupaj $s$ spremembami ideoloških okoliščin, je močno povezan z vprašanjem nadzora in družbene moči. Posamezniki in skupine se pogosto spopadajo glede pomenov preteklosti, saj je uradni spomin vsiljen $s$ strani vladajočih, medtem ko skušajo različne družbene skupine, kot razkrivajo Roy Baumeister, Gallit Dori in Stephen Hastings (1998), skozi lasten spomin ohranjati pozitivno samopodobo.

Kraljevina SHS je v eni državi združila » zmagovalce « (nekdanje državljane Srbije) in »poražence « (nekdanje državljane Avstro-Ogrske, predvsem Hrvate, Slovence, Srbe in Bošnjake). Vojni pohod Avstro-Ogrske nad Srbijo, v katerem so bili na strani napadalcev v velikem številu mobilizirani Hrvati, manjkalo pa ni niti Slovencev niti Srbov, je imel za posledico ogromno število žrtev in hudo ekonomsko škodo. Srbski kolektivni spomin na krvavo bratomorno in versko vojno pa je ostal vir nezaupanja, ki je v veliki meri tudi krojil povojno politiko v Kraljevini SHS.

\section{Spomeniki med zasebnim in javnim / uradnim in subverzivnim}

V Kraljevini SHS so z veličastnimi javnimi spomeniki, postavljenimi z državnimi podporami, slavili srbske vojaške zmage, $v$ državnih spominskih slovesnostih so povzdigovali junaštva srbskih vojakov in dobrovoljcev. Te spomenike so postavljali po srbskih mestih in vaseh, medtem ko jih v drugih delih države - z izjemo Slovenije - ni bilo. Šele po večletnem obdobju zamolčevanja padlih vojakov so se iz stiske svojcev, ki so bili prikrajšani za prostor spominjanja in žalovanja, oglasila mnenja, da je »sramotno «, da večina padlih vojakov ni imela niti skromne plošče $\mathrm{z}$ imeni v cerkvenem zidu ali na pokopališču, da v spomin vsem padlim vojakom še ni bilo niti najskromnejšega spomenika na javnem prostoru, da niso obhajali nobenih slovesnosti v njihov spomin. Večino denarja za spomenike, znamenja in spominske plošče so zbrali verniki sami v obliki izdatnih osebnih donacij ali namenske nabirke med bogoslužji. Zato so ljudje ta spominska znamenja, to je označevalce spomina na prvo svetovno vojno, dojemali kot del njihove lastnine in intimnega, predvsem družinskega spomina na padle in pogrešane vojake ter trpljenje civilistov. Postala so del utelešenega spomina lokalne skupnosti na vojno, ki se je pogosto razlikoval od uradnih interpretacij. Takšna bipolarnost razumevanja vojnih dogodkov se je še posebej izostrila v letih po drugi svetovni vojni, ko je politika, 
osredinjena na pripovedi in spominjanja na drugo svetovno vojno, dopuščala izključno uradno - »učbeniško « interpretacijo, medtem ko je »ljudstvo « ohranjalo pripovedne - narativne oblike spominov.

Postavljanje spomenikov padlim vojakom različnih etničnosti je v Kraljevini SHS tako postalo sekularen ritual, ki je podpiral bodisi » uradne « bodisi »subverzivne « politične vrednote. Spomin na vojno je do leta 1940 postal eden osrednjih političnih torišč, ki je na Slovenskem pomembno vplival na oblikovanje slovenske nacionalne identitete kot različne od jugoslovanske. Govorniki na slovesnostih ob odkritjih spomenikov in komemorativnih svečanostih so redno navajali krivice zaradi neenakopravnega statusa avstro-ogrskih vojnih veteranov z območja Dravske banovine, poudarjali so potrebo po ohranjanju slovenskega jezika ter izpostavljali slovenske narodne posebnosti in katolištvo. Postavljanje spomenikov padlim vojakom avstro-ogrske vojske je bilo odvisno od posameznikov oziroma manjših skupin, ki so znali mobilizirati ljudi, da so prispevali sredstva, saj za razliko od spomenikov padlim vojakom po srbskih mestih in vaseh država postavljanja teh ni podpirala. Najpogostejša oblika je bila spominska plošča, ki so jo praviloma vzidali na steno cerkve ali obzidje pokopališča; na njih so bila vklesana imena padlih vojakov, in to tudi na likovno bolj zahtevnih spomenikih. Imena, praviloma razvrščcna po abecednem vrstnem redu, so ohranjala enakost, vzpostavljeno na bojiščih, vsi padli so bili na ta način razglašeni za junake. $\mathrm{Na}$ spomenikih in spominskih znamenjih vklesana imena so vsem padlim izkazovala čast, nekdaj namenjeno zgolj lokalnim veljakom. Kot ugotavlja Catherine Moriarty, so na ta način postala imena, ki so zasebno v ljudeh vzbujala žalost, vir državljanskega ponosa (1997). Sodelovanje faranov in/ali vaščanov pri velikih javnih spominskih svečanostih pa je utrjevalo vlogo podeželja in kmetstva kot odločilnih pripadnikov naroda.

Zborovanja ob odkritjih spominskih obeležij ali spominskih svečanostih so bila priložnost za izražanje političnih stališčc, zlasti slavnostnih; niso se nanašala toliko na preteklost kot na sedanjost. V Kraljevini SHS je spomin na vojno postal eno osrednjih političnih bojišč, spomeniki padlim vojakom, opravljenim $\mathrm{v}$ vojaške uniforme nekdanjih sovražnih vojsk, pa nekako nadaljevanje vojne z drugimi sredstvi. Z leti je ta boj postajal vse bolj jasno in glasno političen.

Vito Hazler v raziskavi doslej najbolj sistematično in popolno evidentira vse take spomenike, postavljene v slovenskem delu Kraljevine SHS; zgodbe, povezane z njimi, kdo je bil pobudnik in kdo jih je postavljal; s kakšnimi svečanostmi so pospremili njihova odkritja, kako so potekale spominske komemoracije in podobno. 
Poseben položaj so imela spominjanja na padle avstro-ogrske vojake na ozemlju, ki ga je zasedla Italija. Večina pokopališč in spomenikov, ki so jih vse do konca vojne leta 1918 na avstro-ogrski ali italijanski strani postavili v spomin padlim vojakom, je ostala ohranjenih (prim. Prinčič 2018). Na primer v Solkanu ali Braniku so bili novi spomeniki in spominska znamenja namenjeni le italijanskim vojakom. Med njimi je leta 1938 nastalo najbolj znamenito in tudi v Italiji največje pokopališče pri Redipuglii/Sredipolju, v katerem leži okoli 100.000 italijanskih vojakov in ki je bilo vse do papeža Frančiška eno osrednjih prizorišč za obnavljanje spomina o zmagoviti italijanski vojski. Na nekdanji avstro-ogrski strani so po letu 1990 začeli obnavljati objekte. Akterji so bili različni, tako so tudi s sredstvi številnih madžarskih obiskovalcev obnovili madžarsko kapelico pri Vižintinih. Leta 1998, ob sedemdesetletnici konca vojne, so vaščani odkrili spominsko ploščo $\mathrm{v}$ spomin na padle $\mathrm{v}$ vasi Obrov; podomačili so jo tudi $\mathrm{s}$ tem, da so hišna imena napisana $\mathrm{v}$ krajevnem narečju. $\mathrm{Na}$ italijanski strani kaže na zadrege s konkretnimi, lokalnimi memorializacijami spomina na padle dejstvo, da so prvo ploščo vsem padlim postavili v Boljuncu šele leta 2018.

\section{Spomeniki neznanemu junaku/vojaku}

Najbolj značilen znak spomina na strahote vojne je postala grobnica neznanega vojaka, $s$ katero so želeli izraziti spoštovanje padlim vojakom, številnim iznakaženim in mnogim, izginulim brez sledu. Grobnica neznanega vojaka je postala simbol vseh vojnih žrtev določenega naroda, hkrati pa je na način metonimije preživelim omogočala žalovati za padlim svojcem. Postavili so jih navadno v glavnem mestu države, v Parizu in Londonu leta 1920, naslednje leto v Rimu in Washingtonu, še leto pozneje v Bruslju, Pragi in Beogradu, leta $1923 \mathrm{v}$ Bukarešti in na Dunaju. Spominske svečanosti so si bile podobne, udeležili so se jih vodilni civilni, cerkveni in vojaški dostojanstveniki, veterani ter državljani.

Ti zgledi so leta 1927 spodbudili tudi nekdanje slovenske udeležence vojne, ki so začeli razmišljati, kako bi tudi Slovenci postavili grobnico neznanemu junaku. Uresničevanje te ideje je potekalo počasi. Za lokacijo so izbrali Brezje kot osrednje slovensko romarsko središče. Tako so avgusta 1937 blagoslovili temeljni kamen za spomenik neznanemu slovenskemu vojaku. Druga svetovna vojna je prekinila vse aktivnosti za postavljanje spominskih znamenj, in načrt za spomenik neznanemu slovenskemu vojaku je bil pozabljen. 
Spomeniki ohranjajo spomin na pomembne zgodovinske osebnosti ali dogodke, najprej $s$ tem, da so postavljeni na navadno pomembnih lokacijah, a tudi s tem, da omogočajo mesto ritualnim praksam spominjanja na prvo svetovno vojno. Komemoracije, s katerimi posamezniki ali skupnosti izrazijo svojo pripadnost, vzpostavljajo lokalno, regionalno, etnično, nacionalno ali državno entiteto. Komemorativne prakse omogočajo socialno kohezijo in hkrati izključujejo drugega. Rituali so preprosto neizogibni za socialno integracijo (Lukes 1975) kot tudi za socializacijo hierarhij in razmerij, hkrati pa pričajo tudi o rabi moči (Kertzer 1988). Komemorativne prakse, povezane z vojno, že v izhodišču mobilizirajo pristranost (bias); hkrati pa odpirajo vprašanja o razmerju med različnimi diskurzi, na primer med uradnimi, političnimi diskurzi raznih strank, diskurzi medijev, tako imenovanim navadnim, zdravorazumskim (common sense) in subkulturnim diskurzom (Fikfak 2014). Ritualne prakse tako dovolj zgovorno pričajo tudi o sami družbi, skupnostih in ustanovah, ki jih organizirajo (Simonič 2009).

Vojno napoved Srbiji so po mestih avstro-ogrske monarhije sprejeli z velikimi javnimi manifestacijami $\mathrm{v}$ organizaciji civilnih in vojaških oblasti, avstro-ogrsko časopisje jo je ognjevito pozdravljalo z bombastičnimi uvodniki. Tako sta ljubljanski župan in vodja liberalne stranke Ivan Tavčar ter ljubljanski knezoškof Anton Jeglič, ki sta bila še pred svetovno vojno pogosto vsak na svojem bregu, zdaj enoglasno govorila isti bojeviti protisrbski jezik.

Konec vélike vojne je med narode, izmučene od dolgotrajne vojne, neizogibno prinesel nove realnosti z novimi junaki in novimi pozabami. Povojna obnova je terjala ogromno gradnje, marsikje je bilo treba postaviti celo nove temelje. $V$ tem kontekstu se je temeljito spremenil tudi kolektivni spomin ne le na vzroke in posledice vojne, temveč tudi na njene cilje in smotre. $\mathrm{V}$ resnici se narativna podoba o vojni iz časa po koncu vojne tako razlikuje od tiste iz časov med vojno, kot da bi šlo za dvoje povsem različnih vojn s povsem različnimi motivi, cilji in posledicami. Po koncu vojne in ustanovitvi nacionalne države $\gg$ troimenega naroda « je nova državna skupnost potrebovala kot družbeno vezivo nove heroje in simbole, ne nazadnje tudi nove rituale.

V okviru raziskovanja komemorativnih praks, spominskih slovesnosti in produkcije spomina $\mathrm{z}$ njihovo pomočjo velja pozornost posvetiti dvema težiščema spominske produkcije: prvo se jedri v nekaterih zgodovinskih osebnostih, ključnih za nastanek ter potek in konec vojne; osišče drugega pa so sama vélika vojna, njene strahotne posledice in mir. 
Med najpomembnejšimi zgodovinskimi osebnostmi, ki so bile predmet spora in so jim bile posvečene tako slovesnosti kot spomeniki, je zagotovo prvi Gavrilo Princip, za številne »iniciator « vélike vojne; na primer za raziskavo slovenske percepcije je pomemben $\mathrm{Ru}-$ dolf Maister in drugi. Namen diskurzivne analize je razkriti različne interpretacije in rabe zgodovinskih osebnosti, ki so odvisne od osnovne intencije uporabnika. Tako je Princip za Srbe heroj, za Bošnjake atentator. Alenka Bartulović razgrinja ambivalence pogledov nanj, Mitja Velikonja pa ga tematizira v okviru jugoslovanskih diskurzov. Maister je osrednja figura prve svetovne vojne na Slovenskem, ugotavlja Peter Simonič, in hkrati simbol slovenstva dodaja Velikonja. Ti posamezniki, junaki za eno in sovražniki za drugo stran, so postali metafore, ki jih lahko vsakokratni diskurzi uporabljajo in oblikujejo na popolnoma nasprotne načine.

$\mathrm{V}$ drugem gre za rabo spomina na véliko vojno in nekatere pomembne dogodke v njej (na primer soška fronta) za vzpostavljanje in poustvarjanje ekstraktivnih ali inkluzivnih strategij (North 1991). Komemorativne prakse so pogosto povezane tudi z ritualizacijo zmage pri zmagovalcih in poraza pri poražencih, omogočajo vztrajanje pri konceptu žrtve (na primer kosovska bitka 1389), konceptu teritorialnosti (fašizem po véliki vojni) in podobno. Tako je mogoče ugotoviti, da je italijanski, fašistični diskurz, še posebej ob dokončanju največjega italijanskega spomenika svojim vojakom v Redipuglii ali Sredipolju leta 1938, utemeljeval svojo teritorialnost tako na podlagi zgodovinske pravice po zasedbi nekdaj rimskega ozemlja kot »višje kulture «, ki bo civilizirala slovansko ljudstvo. Med temeljnimi oziroma dominantnimi značilnostmi različnih, predvsem emskih vidikov in diskurzov, to je italijanskega, avstrijskega, jugoslovanskega, slovenskega vidika, sta zagotovo osrednji dve, najprej koncept žrtve in koncept izgubljenega ali pridobljenega teritorija, v Avstriji s konceptom nedeljive Koroške, na Madžarskem z izgubo teritorija zaradi trianonske mirovne pogodbe in tako dalje.

$\mathrm{V}$ okviru raziskave praks je poleg vprašanj o razvoju in spreminjanju ekstraktivnih in inkluzivnih strategij pomemben tudi problem sekularizacije, pacifizma. Pri oblikovanju spomina na preteklost je bil zagotovo eden od najpomembnejših procesov evropeizacija - temelj inkluzivne strategije -, v okviru katere se percipirajo tudi vojaški spopadi in v okviru katere je, na primer, leta 2014 nastal tudi evropski inštitut miru. $Z$ etnografsko analizo aktivnosti in semiotično analizo simbolnih prezentacij $\mathrm{v}$ različnih časih lahko na primeru izbranih ritualnih praks, tako državniških kot lokalnih, ugotovimo premike $\mathrm{v}$ dojemanju preteklosti in temeljno spreminjanje uradnih, medijskih, 
common sense in subkulturnih diskurzov tako na ravni govorov, praks kot tudi znakov. V skoraj vseh diskurzih, izjema so le nekateri, na primer italijanski CasaPound, je postalo izhodišče mir, ki se ga dá doseči le $\mathrm{z}$ inkluzivnimi strategijami.

Ritualne prakse »ne pripovedujejo zgodb, temveč udejanjajo določene resničnosti «; tudi »ne razkrivajo informacij, temveč omogočajo realizacijo dejanj « (Houseman 2008). V našem okviru s komemorativnimi praksami udejanjajo določene poglede na resničnost; nanašajo se tako na zgodovinske osebnosti kot na samo véliko vojno, pomembne dogodke in njene posledice. Raziskovanje junakov, slavnih osebnosti, njihove produkcije, imaginacije in reinterpretacije v družbi vse do nedavnega v etnologiji ni veljalo za pomembno. Nekaj zanimanja je bilo za mitološke junake (Šmitek 1998; Stanonik 2007). V zadnjih desetletjih je tako v mednarodnih (Povedák 2014) kot domačih besedilih (Jezernik 2013; Fikfak 2014) več zanimanja za obravnavo historičnih in sodobnih vidikov herojstva.

Med zgodovinskimi osebnostmi, ki so vplivale na slovensko in globalno zgodovinsko pot, je gotovo Gavrilo Princip, sarajevski atentator. Raziskovanje njegovih rab in izrab je v sodobni bosansko-hercegovski družbi dolgo časo obstalo na obrobju zanimanja. Ob približevanju obeležitve stote obletnice začetka vélike vojne so se pojavile osamljene, zlasti zgodovinske, a tudi umetnozgodovinske študije, ki so z analizami diskurzov ugotovile različne interpretacije osrednjega akterja prelomnega dogodka (Kamberović 2014), ugotavlja Alenka Bartulović, ki analizira rabo Gavrila Principa v samem Sarajevu (2018). Komparativna terenska etnološko-antropološka raziskava dveh figur prve svetovne vojne, to je Gavrila Principa in Rudolfa Maistra (Velikonja 2018) nadgrajuje spoznanja zgodovinarjev z etnografskim gradivom o » posmrtnem življenju « in ritualnem spominjanju pomembnih zgodovinskih osebnosti. Raziskava vključuje tudi turistične in popularnokulturne rabe osrednjih figur sarajevskega atentata.

Reinterpretacije delovanja zgodovinskih osebnosti namreč odsevajo sodobne (politične) težnje ter razkrivajo upe in težnje, ki so postali ena bolj zanimivih tem sodobnih antropoloških študij (Appadurai 2004; Bartulović 2012; Zournazi 2002). S temo vélike vojne in družbenim življenjem po njej so se ukvarjali predvsem mariborski zgodovinarji: Franc Rozman, Vlasta Stavbar, Dragan Potočnik in Darko Friš. Nekaj gradiva o spomenikih je predstavil tudi umetnostni zgodovinar Sergej Vrišer, medtem ko je France Rozman analiziral politične rituale. Etnološko je vprašanja obravnavala hrvaška etnologinja Dunja Rihtman Auguštin (2002), pozneje Reana Senjković (2002). V Sloveniji so se s političnimi rituali ukvarjali Peter Simonič (2009), predvsem 
s stališča konstituiranja države, Jurij Fikfak s stališča spravnih procesov (2009) in medigre različnih diskurzov (2015), Habinc (2011) pa v povezavi s socialističnimi rituali. $\mathrm{V}$ mednarodni etnološki in antropološki skupnosti so postali politični rituali zanimivi v 1970-ih in 1980-ih letih, ko je postalo jasno, da so eno od osrednjih kategorij tudi $v \gg$ razvitih civilizacijah «, torej domovinah antropologije (Kertzer 1988).

$\mathrm{V}$ raziskavi je pozornost namenjena komemorativnim praksam in praksam produciranja, a tudi spreminjanja spomina na začetek vélike vojne. $\mathrm{V}$ ospredju zanimanja je sarajevski atentat, ki je navadno razumljen kot osrednji povod za krvavo vojno. Ob stoletnici sarajevskega atentata je v Sarajevu pred mestno hišo (vijećnico), ki jo je zgradila avstro-ogrska oblast in požgala srbska vojska v začetku 1990-ih let, potekala prireditev ob obeležitvi stoletnice začetka vélike vojne. Slovesnost, na kateri so nastopili dunajska filharmonija in nekaj sarajevskih solistov, je sprožila precejšnje negodovanje politične oblasti, še zlasti v Republiki Srbski, kjer so se skupaj s srbskim političnim vrhom odločili, da se dogodka ne bodo udeležili in da bodo na svoj način počastili obletnico sarajevskega atentata. Svojo »vzporedno « slovesnost so pripravili v Višegradu, kjer je filmski režiser Emir (Nemanja) Kusturica odprl projekt, ki naj bi služil kot turistična destinacija in središče srbske kulture v Bosni in Hercegovini - »Andrićgrad «. V njem je posebno mesto namenil organizaciji Mlada Bosna: ena od ulic nosi njeno ime, na ogled je velik $(8,5$ x 3,5 m) mozaik, na katerem so upodobljeni njeni člani. Sočasno so v vasi Obljaj pri Bosanskem Grahovu odprli prenovljeno rojstno hišo Gavrila Principa.

\section{Zgodovinske osebnosti in ambivalence}

V ospredju komemorativnih praks in spominskih slovesnosti v sodobni Bosni in Hercegovini, ki je razdeljena na dve entiteti (Federacijo $\mathrm{BiH}$ in Republiko Srbsko), je konflikt med različnimi interpretacijami preteklosti, ki se odraža prav v razumevanju Gavrila Principa kot tudi v prostorskih vpisih spomina (spomeniki, poimenovanje ulic, mostov in tako dalje). Podobe Gavrila Principa v političnem in medijskem diskurzu so se spreminjale: $v$ Bosni in Hercegovini je po vojni v 1990-ih letih postal za nekatere terorist, ohranil ali celo okrepil pa je junaški status v Republiki Srbski. Ta izključevalna binarnost pogledov pa je navadno slepa za vmesne in bolj uravnotežene predstavitve omenjenega obdobja in njenih ključnih figur. Komparativna študija, ki temelji na etnografskem terenskem delu, diskurzivni analizi in pregledu arhivskega gradiva, omogoča spoznavanje heterogenih interpretacij osrednjega lika sarajevskega atentata, njegovih žrtev in političnih 
implikacij vojaškega konflikta; zajema tudi politične manipulacije in njihove učinke (oziroma kontraučinke) v sodobni bosansko-hercegovski družbi. Institucionalno ohranjanje spomina vselej poskuša utišati alternativne spomine in na ta način stkati homogene, pogosto nacionalizirane naracije o preteklosti (Jezernik 2013). Kolektivni spomin in zgodovinske naracije so se prilagajali družbenim okoliščinam ter ideološkim zasukom dvajsetega in enaindvajsetega stoletja. Gavrilo Princip je v socialistični Jugoslaviji zasedal pomembno mesto med jugoslovanskimi heroji in borci za združitev, kar se je kazalo tudi v sarajevskem mestnem tkivu. $\mathrm{Na}$ mestu atentata, na začetku nekdaj Principovega, danes Latinskega mosta (Latinska ćuprija), je le leto dni stal spomenik Francu Ferdinandu in soprogi Sofiji; po koncu vojne so oblasti spomenik prestavile $\mathrm{v}$ muzej in ustvarile prostor za počastitev novega heroja. Spominsko ploščo so sicer postavili v času SFR Jugoslavije, pod njo pa odlitek Principovih stopinj, to je na mestu, od koder je Princip streljal. Odlitek je vse do leta 1995 pomembno sooblikoval izkušnjo mnogih sarajevskih otrok, ki so skupaj s turisti z veseljem stopali v stopinje takratnega junaka. Tovrstne zgodbe, ki jih razkrije etnografsko delo, pogosto ostajajo prezrte $v$ analizah spomina in komemoracijskih praksah, ki so bolj osredotočene na institucionalizirane in organizirane komemoracije. Paul Connerton (1989) ugotavlja, da je prav telesna izkušnja ključna za pomnjenje; habituirana performanca pa spomin vpisuje v telo. Zato je bistveno razkriti tudi intimne prakse $\gg$ komunikacije $\ll s$ spomenikom.

Politična (iz)raba Gavrila Principa je zlasti v bosansko-hercegovski družbi stalnica, posebej v času, ko potekajo volitve in politične bitke. Vendar statusa Gavrila Principa ni moč razumeti brez statusa njegove žrtve - prestolonaslednika Franca Ferdinanda. V odnosu do dveh ključnih likov sarajevskega atentata lahko razbiramo tudi različne percepcije dveh naddržavnih tvorb, Avstro-Ogrske in Kraljevine SHS oziroma Jugoslavije. Tako je, na primer, ob iniciativi za ponovno postavitev spomenika Francu Ferdinandu in njegovi soprogi Sofiji nekdanji podpredsednik sarajevskega mestnega sveta Emin Švrakić omenil, da je bila avstro-ogrska vladavina zelo pomembna za razvoj Bosne in Hercegovine. Slednja je bila vedno v dobrih odnosih z Avstrijo, kar nedvomno priča tudi o (kolektivni) pozabi oziroma ignoriranju napak in slabosti kolonialne avstro-ogrske politike. Skozi dinamiko iniciativ za postavljanje in odstranjevanje spomenikov lahko med drugim spremljamo odnos do imperialnih in naddržavnih zapuščin v sodobni Bosni in Hercegovini. Bosansko-hercegovske težnje po približevanju EU in živi spomini na vojno v 1990-ih letih nedvomno vplivajo na spominske rekonstrukcije ter usmerjajo komemorativne prakse, pri čemer 
so v Bosni in Hercegovini prisotni tako evropocentrični diskurzi kot nostalgične naracije.

Druga, posebej na Slovenskem pomembna zgodovinska osebnost vélike vojne, ki je omogočala ambivalentne odzive, je general Svetozar pl. Boroević de Bojna, krajinski Srb, poveljnik avstro-ogrskih enot na soški fronti. Generala Boroevića je ljubljanski občinski svet $\gg \mathrm{Z}$ velikim navdušenjem « izvolil za častnega meščana, po koncu vojne pa ga je ljubljanski občinski svet črtal s seznama častnih meščanov. Nove oblasti so mu celo prepovedale vrnitev v domovino (prim. Nećak in Repe 2010; Svoljšak 2011; Simčič 2011). Nasproti obema herojema, ki povzročata ali omogočata konfliktne položaje in ambivalentno recepcijo, je tretja, za Slovence pomembna zgodovinska osebnost general Rudolf Maister (prim. Simonič 2018; Velikonja 2018), ki je z vojaško silo dosegel premik meje na sever. $Z$ intervencijo svojih borcev ob koncu vélike vojne je omogočil tudi dokončno prevlado Slovencev v Mariboru in izpeljal zamisel, ki jo je že pol stoletja prej zasnoval škof Slomšek. Obema, generalu Maistru in škofu Slomšku, so danes v mestu posvečene redne letne prireditve, pogosto sta reproducirana $\mathrm{v}$ različnih vodnikih, množičnih medijih in učbenikih; njuna markantna spomenika danes stojita na dveh osrednjih mariborskih trgih.

\section{$\underline{\text { Ritualizirane produkcije spominjanja vélike vojne (in miru) }}$}

Številne žrtve na vseh v véliki vojni udeleženih straneh, porazi in zmage, spremembe državnih meja ali zagotovitev etnično »čiste « pokrajine so že v prvih letih po vojni omogočili številne komemorativne slovesnosti. Predvsem v prvih letih in desetletjih po vojni so zanje značilne ekstraktivne oziroma izključevalne strategije ter izrazito državotvorni, narodotvorni vidik. Nacionalizacija prostora in ljudstva se tako zgodi $\mathrm{v}$ vseh štirih državah, v katerih so živeli Slovenci. Italija, zmagovalka v prvi svetovni vojni, je z Rapalsko pogodbo dobila obsežen del ozemlja, naseljenega s slovenskim in hrvaškim življem, in je takoj začela izvajati dosledno homogenizacijo - italijanizacijo neitalijanskega in italijanskega prebivalstva (Lyttelton 2002), pri čemer se je sklicevala tudi na kontinuiteto z rimskim imperijem. $S$ postavitvijo kostnic (na primer v Kobaridu ali Sredipolju / Redipuglia), drugih spomenikov in znamenj ter ritualnimi slovesnostmi je konstituirala podobo italijanstva, obnavljala koncept žrtve in zmage nad neciviliziranim, neitalijanskim. Novonastala Avstrija je za razmejitev z novonastalo Kraljevino SHS, pozneje Jugoslavijo, tudi enega od instrumentov svobodne odločitve, to je plebiscit na Koroškem leta 1920, v naslednjih letih uporabila kot sredstvo za intenzivno germanizacijo. Ritualne slovesnosti so v obeh 
primerih poudarjale in zagotavljale nacionalni vidik, italijanskega ali nemškega, ter ga gradile in konstituirale tudi z izključevanjem drugih etničnosti (Slovencev, Furlanov, Romov) (Karner 2005). S Trianonsko pogodbo je Prekmurje postalo del Jugoslavije in le manjši del, to je Porabje, je pripadel Madžarski, ki je intenzivno skrbela za madžarizacijo tega ozemlja.

Ritualne slovesnosti, njihova vsebina in program so zavestno gradili podobo monolitne države in pripadnika, ki se konstituira prav v odklonilnem odnosu do drugačnega, drugega, navadno drugojezičnega ali drugokulturnega. Raziskava kaže na to, kako so ritualne prakse in spominjanja na véliko vojno (deloma tudi drugo) $\mathrm{v}$ vseh treh državah odsevale strategije večinskega naroda, uradnih, medijskih, common sense diskurzov in kako je, na primer, slovensko prebivalstvo pod Italijo razvilo nekatere elemente in strategije tihega protiodpora.

V Kraljevini SHS oziroma pozneje v Jugoslaviji je bilo ritualno spominjanje ambivalentno, na Slovenskem pa v marsičem zaznamovano $s$ položajem poraženca $\mathrm{v}$ vojni in v veliki meri na ravni družinskih, vaških skupnosti usmerjeno v osebne tragedije. Na Slovenskem je obveljal etnocentrični, nacionalni vidik prireditev, tudi zaradi radikalnega preloma $\mathrm{z}$ avstrijsko državo in dediščino, ki se je po letu 1918 odražal v kolektivni pozabi, pa tudi namernem brisanju velikanov in dogodkov nemškega izvora zaradi konstruiranja kontinuitete projugoslovanstva in sokolstva. Tako je bilo šele v okviru razstave Nemci v Mariboru, ki je bila del projekta Evropska prestolnica kulture leta 2012, nekdanje nemško govoreče prebivalstvo znova prepoznano kot pomemben nosilec mariborskega gospodarskega in političnega življenja v preteklosti. Mesto se je zavedlo svoje prehodnosti, večjezičnosti, nekdanje meščanskosti. Odkritje nemške identitete je sovpadlo $s$ slovenskim pridruževanjem evropski skupnosti z večinoma gospodarsko in ideološko usmeritvijo na nemški in ostale evropske trge.

Ob teh ritualnih praksah, ki so jim osnova nacionalizirajoče, esktraktivne, izključevalne strategije, je treba opozoriti tudi na primere tistih novodobnih praks, ki so inkluzivne, spravne in so jih iniciirale različne skupine, na primer Concordia et pax na Goriškem, v veliki meri motiviranimi s personalističnim izhodiščem. Nove težnje mogoče najbolje ponazarja komemorativna slovesnost v Sredipolju / Redipuglii leta 2014 ob stoletnici začetka vélike vojne, kjer je papež Frančišek po obisku obeh pokopališč, avstro-ogrskega in italijanskega, in ob spominu na svojega starega očeta, ki se je boril v teh krajih, poudaril nesmiselnost katerekoli vojne. 
Dediščino prve svetovne vojne razumemo kot nenehni metakulturni proces (Kirshenblatt-Gimblett 2004; Herzfeld 2010), v katerem različni družbeni akterji preoblikujejo in uporabljajo zapuščino vojne, da bi ustvarili kolektivno identiteto $\mathrm{v}$ sedanjosti, reinterpretirali medsebojna razmerja ali oblikovali specifične reprezentacije. Tako $\mathrm{v}$ turizmu potekajo procesi ustvarjanja turističnih podob in mitov (Selwyn 1995), ki so neločljivo povezani z reprezentacijami kulturne dediščine in identitete, vprašanji avtentičnosti (MacCannell 1973), kulturnega performansa (Boissevain 1996) in kulturne kreativnosti v okvirih sodobnega ekonomskega razvoja (Richards in Wilson 2007). Različni kraji artikulirajo različne osebne in kolektivne spomine, služijo ciljem lokalnih elit, usmeritvam nacionalnih držav ali transnacionalnih entitet, kot je EU. Najpogostejše orodje za doseganje teh učinkov so dediščinski diskurzi, objekti in krajine.

Politika dediščinske konstrukcije in vpisov v krajino vključuje tudi spremembe v vsakodnevnem življenju ljudi. Krajine se umešča $\mathrm{v}$ dediščinske sezname, distribuira $\mathrm{v}$ režime vidnosti in prikrivanja ter spomina in pozabljanja (Scott in Selwyn 2011), saj »snovna « dediščina vedno implicira tudi »nesnovne « značilnosti (Orbaşli in Woodward 2012). Spominska krajina ni le objektivna danost ali podlaga za človeške dejavnosti. Raziskave v etnologiji, geografiji, kulturologiji in delno $\mathrm{v}$ arheologiji so pripeljale do perspektive, v kateri krajino razumemo kot del človeškega izkustva, oblikovanja družbenosti, odnosov, spominov in zgodovin (Feld in Basso 1996). $\mathrm{V}$ raziskavah krajine je po eni strani postal pomemben fenomenološki pristop $\mathrm{k}$ razumevanju odnosa med družbenostjo in izkušnjo krajine (Ingold 1993, 2000; Tilley 1994; prim. Hirsch in O'Hanlon 1994), po drugi pa kontekstualizacija političnih procesov (na primer Bender 1993), nacionalizacija kulture in produkcija dediščine (Löfgren 1989) ter iskanje avtentične krajinske izkušnje (Selwyn 2004). Tovrstne raziskave ugotavljajo, da so krajine podvržene reinterpretacijam in fizičnim spremembam, na katere vplivajo družbeni in politični procesi ter različni akterji (Tilley 1994; Bender in Winer 2001). Vojne krajine so največkrat obravnavali zgolj skozi vojaško zgodovino, ne pa kot »nenehen proces, ki je vplival na življenja ljudi po letu 1914« (Saunders 2001: 37). Saunders ugotavlja spremembe $\mathrm{v}$ intepretacijah $\mathrm{v}$ obdobjih med véliko vojno (uničenje zemlje in življenja), med vojnama (spominske in romarske krajine), po drugi svetovni vojni (spominske in turistične krajine), nedavno pa so razumljene predvsem kot dediščinska krajina. 
Po vojni so bila bojišča spremenjena $\mathrm{v}$ krajine romanj in turizma (Lloyd 1998), spominov, obeleženih v spomenikih, poteh, na pokopališčih in podobno (Winter 1995), v zadnjem desetletju pa krajine oblikovanja lokalne, nacionalne in evropske dediščine. Evropeizacija dediščine vojne ima lahko več pomenov (Harmsen in Wilson 2000); številni med njimi se nanašajo na normativne, celo teleološke procese, ki jih lahko opredelimo predvsem v smislu končnih ciljev (Checkel in Katzenstein 2009). Naš pristop k preučitvi čezmejnega medsebojnega delovanja med različnimi spominskimi parki po Evropi sloni na etnološkem razumevanju evropeizacije kot družbenega procesa, ki se opira in vpliva na preokvirjenje odnosov med evropskim in nacionalnim, pri čemer je nacionalno osrednja kategorija identitete (Borneman in Fowler 1997; Bellier in Wilson 2000; Bajuk Senčar 2014). V posebnem sklopu prispevkov Jaka Repič, Boštjan Kravanja in Tatiana Bajuk Senčar obravnavajo ta vprašanja $\mathrm{z}$ vidika antropologije prostora, vidik, ki šele zadnje čase prodira $\mathrm{v}$ ospredje raziskovalnega interesa $\mathrm{v}$ zvezi $\mathrm{s}$ prvo svetovno vojno.

V Avstrijskem cesarstvu je enega od vrhuncev javnega glorificiranja junaških podvigov že med samo vojno pomenila velika vojna razstava. V cesarski prestolnici so jo odprli 1. julija 1916, da bi z njo pokazali obiskovalcem, kje in s čim so cesarske armade dosegle zmage na bojnih poljih. Razstava je bila utemeljena na tradicionalnem pojmovanju junaštva in je obiskovalcem predstavljala predvsem bogato zbirko trofej v obliki sovražnikom zaplenjenega orožja in drugega vojnega plena. Vojne trofeje so poveličevale uspehe cesarske vojske in gledalcu sporočale, kako so bili in bodo neuspešni vsi napori njihovih nasprotnikov, da bi jo uničili, zahvaljujoč junaštvu in mučeništvu cesarjevih vojakov. $\mathrm{Na}$ vojni razstavi je bil poseben oddelek, namenjen vojaškim grobovom in spomenikom. Sodobniki so menili, da je bil v krvavi evropski vojni za zgodovino pomemben prav vsak dan. Ker izkušenj ni moč zapisati le $s$ crnilom in peresom, je bilo treba zbirati spomine in predmete iz vojne same, da bi potomcem mogli ohraniti pravo podobo vojne. $\mathrm{V}$ vseh državah udeleženkah spopada so že v prvem letu vojne mislili na ustanovitev vojnih muzejev, virov informacij bodočih zgodovinarjev in beletristov. V Avstriji so načrtovali osnovanje takih muzejev po vseh večjih mestih cesarstva. Vojni muzeji so bili namenjeni predvsem za propagandne cilje, pri njihovi postavitvi pa naj bi sodelovale deželne centrale za domovinsko varstvo iz vse države. Prvega so zasnovali v cesarski prestolnici, potem so jih začeli pripravljati tudi v drugih večjih mestih. Sredi januarja 1915 se je pojavil predlog, da bi v Kranjskem deželnem muzeju »Rudolfinumu « ustanovili poseben vojni oddelek. Istega leta je kranjski deželni glavar Ivan Šušteršič osnoval pripravljalni 
odbor za ustanovitev deželnega vojnega muzeja. Ta je sestavil delovni načrt in predlagal zbiranje predmetov, $s$ katerimi bi lahko opremili majhne vojne muzeje v Ljubljani, na Bledu in Bohinjski Bistrici.

$S$ koncem vojne in nastankom nove nacionalne države $\gg$ troimenega naroda « so se nekdanji načrti o muzejih svetovne vojne, postavljenih v čast in slavo cesarske armade, umaknili z dnevnega reda. $\mathrm{Na}$ začetku 1930-ih let je Zveza bojevnikov znova začela razmišljati o vojnem muzeju in $\mathrm{v}$ ta namen začela zbirati razne zanimivosti z bojišč, predvsem slike, dnevnike, knjige in podobno. Vendar je bila prva muzejska razstava o svetovni vojni postavljena šele pol stoletja pozneje, in sicer v lokalnem muzeju Tomaža Godca v Bohinjski Bistrici.

V tem sklopu projekta je bila raziskava osredinjena na vprašanje, kako so po letu 1918 (re)interpretacije svetovne vojne na različne načine in različno intenzivno vplivale na ohranjanje dediščine vojne v slovenskem (in jugoslovanskem) prostoru. Dediščina kot metakulturni proces je odvisen od nenehnih pogajanj o pomenu preteklosti za oblikovanje skupnosti in kolektivne identitete v sedanjosti. Dediščinjenje vojne nudi podlago za ponovni premislek, rekontekstualizacijo in preoblikovanje socialnega spomina na vojno.

Dediščino vojne raziskujemo s treh vidikov. Najprej gre za številna mesta, na katerih poteka kontinuirano dediščinjenje vojne vse od konca vélike vojne naprej, točke, ki predstavljajo mejnike v krajini socialnega spomina o vojni - vključno z muzeji, zbirkami in spomeniki, $s$ fokusom na sodobna spominska mesta in prakse. Zelo pomemben in v evropskem merilu velikokrat spregledan je prostor nekdanje soške fronte kot spominske krajine in prostora novih oblik (re)memorializacije in dediščinjenja vojne. Središče zadnjega fokusa pa je uokvirjanje teh praks in oblik v sodobne evropske dediščinske diskurze in prakse, ne nazadnje tudi sami procesi evropske integracije.

\section{Mesta dediščinske produkcije}

Muzejskih razstav je bilo v slovenskem prostoru med obema vojnama zelo malo. Tudi po letu 1945 so bile na slovenski muzejski sceni teme, povezane s prvo svetovno vojno, izjema, medtem ko so čas med obema vojnama ter obdobje druge svetovne vojne in socialistične revolucije na različne načine prikazovali v skorajda vsakem lokalnem, regionalnem in nacionalnem muzeju. Zato so fokus muzejskega dela raziskave predvsem nove naracije spominov na prvo svetovno vojno, ki so se začele z nastankom Republike Slovenije, torej s pojavom novih tendenc v nacionalni zgodovini oz. nacionalnem spominu, kakor se je afirmirala predvsem v muzejih. 
Po letu 1991 so namreč različni akterji začeli obnavljati pozabljene spomenike in postavljati nove. Druga svetovna vojna, ki je v socialistični Jugoslaviji prvo svetovno vojno tako rekoč izrinila iz javnega spomina, je po letu 1991 postala problematično zgodovinsko obdobje, ki naj bi » razdelilo Slovence «, medtem ko prvo svetovno vojno interpretirajo kot čas krvavih bojev med narodi, iz katerih pa lahko danes potegnemo nauk o »univerzalni « vrednoti mednarodnega miru. $\mathrm{K}$ drugačnemu odnosu do spomenikov so prispevali tudi novi integracijski procesi v Evropi v 1990-ih letih, ki so poudarjali evropsko zgodovino in mednarodno sožitje (pri čemer je spomin na vojno služil kot opomin) ter njim odgovarjajoče lokalne iniciative za obujanje spomina na »soško fronto «, ki so največji uspeh doživele leta 1993 s podelitvijo muzejske nagrade Sveta Evrope muzeju v Kobaridu. Kobariški muzej je $s$ svojimi prezentacijami in reinterpretacijami prve svetovne vojne omogočil aktualizacijo vélike vojne; razvoj vojne dediščine prve svetovne vojne se je $\mathrm{v}$ kontekstu vseevropskega obeleževanja začel leta 2014 ob stoletnici in se nadaljeval še vse do leta 2018. Kobariški muzej prve svetovne vojne je hkrati tudi največji in najuspešnejši zasebni muzej pri nas, ki je v Sloveniji kot prvi v muzealsko prakso uvajal načela takrat trendovskega pojma »ekomuzeja «.

Ostali slovenski muzeji, na primer Muzej novejše zgodovine Slovenije, so se namreč ponovne aktualizacije dediščine prve svetovne vojne lotili šele v zadnjih letih. $\mathrm{Z}$ ustanovitvijo Nacionalnega odbora za obeleževanje 100-letnic 1. svetovne vojne (2014-2018) poleti 2012 se je Slovenija dejavno vključila v vseevropsko počastitev stoletnice začetka svetovne vojne, pri čemer so se v »skladu s slovensko izkušnjo te vojne in kolektivnim spominom odločili za delovanje $\mathrm{v}$ duhu preseganja delitev, ki so leta 1914 Evropo pahnile v vojno, krepitve idej sobivanja in strpnosti ter medkulturnega in medgeneracijskega dialoga «.

$\mathrm{V}$ prizadevanjih za ohranjanje spomina in dediščine prve svetovne vojne zavzema pomembno mesto javna spomeniškovarstvena služba, ki že dobrih 30 let uspešno razvija doktrino varstva svetovne vojne in strokovno nadzoruje varstvene oblike in prezentacije. $\mathrm{Na}$ območju Slovenije so evidentirane 303 enote kulturne dediščine. V današnjih seznamih so ti objekti označeni kot memorialni spomeniki (skulpture, znamenja, plošče, pokopališča, parki in drugo), medtem ko so bili prej večinoma poznani kot zgodovinska dediščina oziroma spomeniki različnih vrednostnih kategorij. Največ teh enot je registriranih v zahodni in severozahodni Sloveniji, in sicer kar 146 na območju Območne enote ZVKD Nova Gorica, medtem ko je drugje teh enot registriranih 157. Podatki še niso povsem dokončni, saj se s sistematičnimi pregledi tovrstne dediščine poleg spomeniškovarstvenih zavodov 
ukvarjajo tudi različne raziskovalne ustanove (Arzenal - SAZU), podjetja (Pogrebno podjetje Maribor), fundacije (Fundacija Pot miru), javni zavodi (Knjižnica Ivan Potrča Ptuj), društva in posamezniki.

\section{$\underline{\text { Krajina soške fronte }}$}

Soška fronta je bilo eno največjih, najbolj tragičnih in v glavnem spregledanih bojišč med prvo svetovno vojno. Naseljeno z etnično slovensko večino in v ob južnem delu reke Soče z Italijani, Furlani in Nemci je bila del pogajanj in dogovora med trojno antanto in Italijo, ki je leta 1915 napovedala vojno Avstro-Ogrski. Legenda pravi, da je to ozemlje obiskal Dante Alighieri (Kozorog 2012) in je že zaradi tega v italijanski javnosti veljalo za del italijanskega teritorialnega horizonta. $\mathrm{O}$ tem na nek način priča tudi eden od tragičnih junakov v Hemingwayu roman Slovo od orožja, ki pokrajino dojema kot del Italije (Hemingway 2014 [1929]: 102). Po mnenju Johna R. Schindlerja so razlogi za zanemarjanje in pozabljanje fronte, $\mathrm{v}$ kateri se je bojevalo več kot milijon vojakov, od katerih jih je bilo več kot 300.000 ubitih, preprosto dejstvo, da za večino zgodovinarjev $\mathrm{v}$ angleškem jeziku bitke in bojišča vojne, ki se niso zgodile na zahodni fronti oz. niso vključevala angleško govorečih vojakov, niso bili zanimivi. Tako je, pravi Schindler, soška fronta pozabljena (Schindler 2001: xiii). Pozabi s strani zgodovinarjev pa kljubuje literarna izkušnja, roman Ernesta Hemingwaya Slovo od orožja, ki je eno prvih splošno znanih pripovedi, ki jih ljudje povezujejo z dogajanjem na soški fronti od 1915 do 1917 . Po eni strani omogoča prepričljivost romanopisca, nobelovca, prepoznati zelo raznolike načine, kako so posamezniki doživljali vojno, na drugi pa zapelje bralca, da verjame, da je literarni junak in pisatelj ena in ista oseba. Njegov neposredni jezik, ki združuje novinarski ali »staccato slog « časnika Kansas City Star z naturalističnim literarnim slogom, naredi izkušnje literarnega junaka, poročnika Frederica Henrya, na soški fronti od sredine 1916 do 1917 ali do bitke pri Kobaridu oprijemljive in realne. Tako se nam ob pogledu na pisatelja, ki se zazre v nas v prvem nadstropju Kobariškega muzeja tik pred reliefom bojišča, ustvari iluzija realnosti.

Eden mednarodno najuspešnejših tovrstnih projektov je prav gotovo leta 2000 začeti projekt Poti miru; gre za znanstveno nadgradnjo predhodnih lokalnih dediščinskih iniciativ. Omogočil je spreminjanje gorske krajine na način, da $\mathrm{z}$ obnovo bunkerjev in vojaških poti postaja muzej na prostem, hkrati pa dobiva značaj zgodovinske krajine. Nekdanje vojaške poti, pozneje pozabljene ali v rabi le kot planinske poti, se danes reinterpretirajo kot spominske poti, ki imajo tudi 
rekreacijski, turistično razgledni in kulturnozgodovinski značaj. Projekt oblikovanja krajine ima tudi izrazito protokolarno funkcijo. Leta 2012 sta predsednik Slovenije dr. Danilo Türk in predsednik Italije Giorgio Napolitano postala častna pokrovitelja projekta »Poti miru od Julijskih Alp do Jadrana «, najbolj eminentnega prispevka Slovenije $\mathrm{k}$ vseevropskemu organiziranemu spominjanju stoletnice prve svetovne vojne. Kljub temu da ima vojna dediščina številne partikularne pomene, gre pri tem tudi za dejavno sodelovanje novih EU periferij v oblikovanju sodobnih dediščinskih evropskih idejnih krajin. V slovenskem primeru gre torej za novo evropeizacijo slovenske zgodovine. $\mathrm{Na}$ primeru Gornjega Posočja in širšega območja Julijskih Alp tako raziskava ugotavlja, kako se z obnovo in postavljanjem spomenikov prve svetovne vojne spreminja tudi družbena percepcija spominske krajine vojne in miru.

Območje Gornjega Posočja, kjer je bila v véliki vojni soška fronta (prim. Štepec 2018), je z dobro ohranjenimi ostanki bojišč »soške fronte « še posebej primerno za doživljanje krajine, saj se ob številnih spomenikih, napisih in vpisih (inscriptions) v krajini (Tilley 1994; Ingold 2000) spomin na vojno danes proizvaja skozi sodobne $\gg$ avtentične « oblike krajinskega izkustva (Selwyn 1995; 2004), kot so hoja po poteh iz prve svetovne vojne, obiskovanje spomenikov, komemoracij ali gibanje skozi rove nekdanjih bojišč. Potem, krajem in objektom, ki so nastali med vojno, so lokalne skupnosti, uporabniki, državne institucije, mednarodni programi in projekti v različnih obdobjih spreminjali pomene, s tem pa tudi interpretacijo njihove zgodovine in kolektivnega spomina. Socialna konstrukcija spominske krajine vojne in miru odraža politični proces reinterpretacije in produkcije dediščine lokalne, nacionalne in evropske zgodovine in spomina, obenem pa zajema tudi fizične in simbolne rekonfiguracije krajev, poti in spominskih objektov.

Med obema svetovnima vojnama območje današnje Primorske ni bilo del Dravske banovine, temveč Kraljevine Italije. Prvi spomeniki so na tem območju nastali že med samo vojno, denimo cerkev sv. Duha na Javorci, ki je obeleževala avstro-ogrske žrtve. Po vojni, ko je območje pripadlo Italiji, pa so številni spomeniki obeleževali italijanske žrtve. Zaradi izkušnje fašizma so nekateri italijanski spomeniki po drugi svetovni vojni, torej v novi državi Jugoslaviji, propadali. Tudi drugi spomeniki prve svetovne vojne so na območju nove države začeli propadati, saj je iz ideoloških razlogov primat med zgodovinskimi dogodki dobila druga svetovna vojna.

$\mathrm{Na}$ območju, kjer je potekala soška fronta, je danes produkcija dediščine prve svetovne vojne posebej izrazita, saj zajema državne in zasebne institucije, organizacije ter iniciative posameznikov. Podobno 


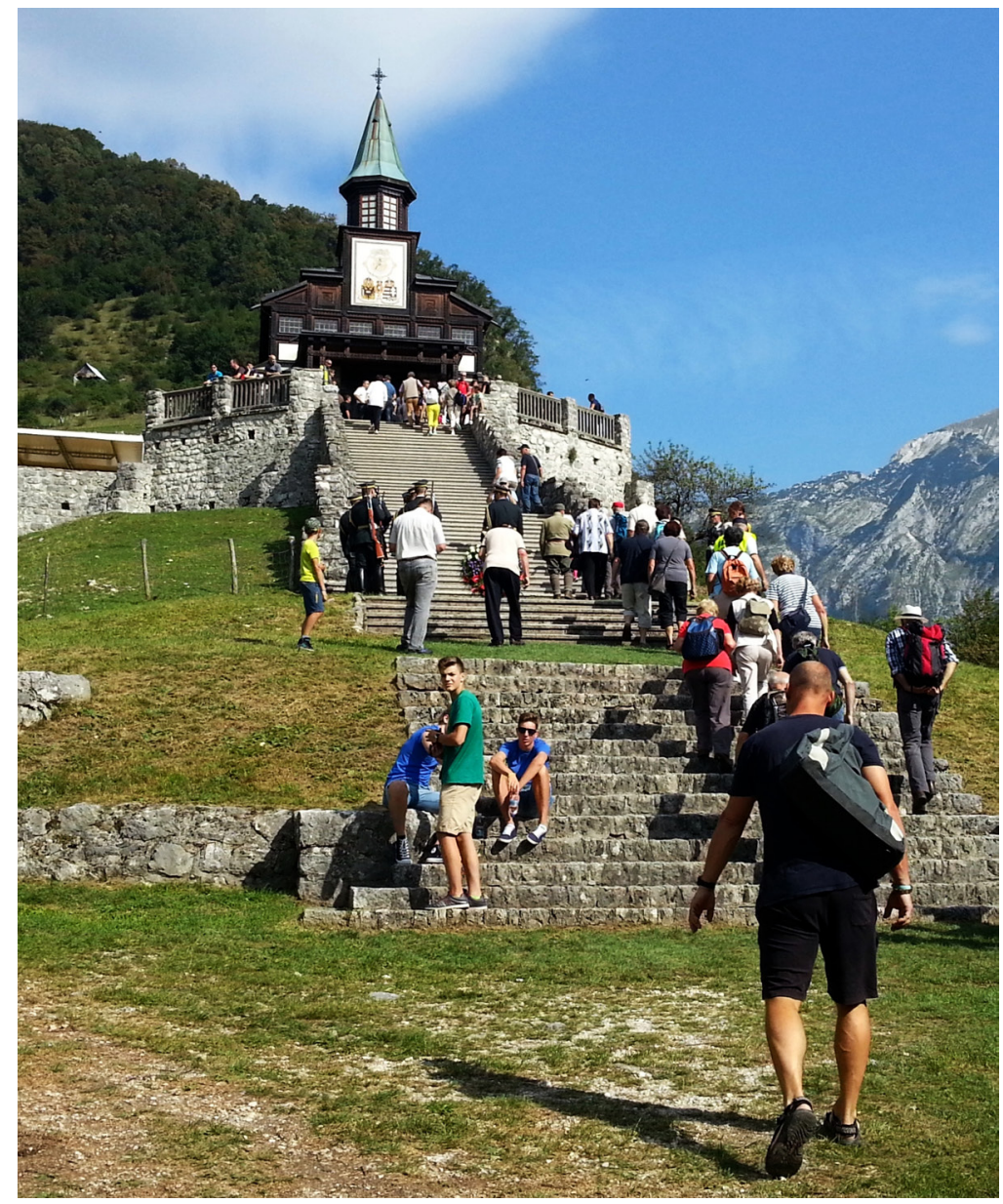

Slika 2: Ob stoletnici postavitve cerkve v Javorci (foto: Miha Kozorog, september 2016).

kot Saunders ugotavlja za zahodno fronto, je tudi soška fronta postala simbolna krajina spomina, kjer se $\mathrm{z}$ obiskovanjem poti, spomenikov in muzejev oblikujejo osebne in lokalne identitete ter nacionalni spomin na véliko vojno (Saunders 2001). Prizadevanja različnih akterjev se odražajo v skrbi za množična grobišča, obnavljanju spomenikov, ki so v času Jugoslavije propadali, urejanju zasebnih in javnih muzejskih zbirk, konfiguriranju spominske vojne krajine $\mathrm{z}$ obnavljanjem vojaške infrastrukture in poti, znanstvenem raziskovanju in pripravi registrov padlih vojakov za javno uporabo ter vključevanju v mednarodna združenja, programe in pobude. Glavni funkciji vseh teh prizadevanj sta pravzaprav dve: turistično-ekonomsko-razvojna na lokalni in protokolarna na nacionalni ravni. 
$S$ kompleksnim in interdisciplinarnim razumevanjem dediščine prve svetovne vojne so se oblikovale tudi vrednostne predstave o podobi memorialne kulturne krajine in spomenikov. Na nekaterih območjih Slovenije je slikovit alpski in mediteranski kulturni poselitveni in naravni prostor pridobil videz vojaško »adaptirane « spominske krajine. Obnovljena pokopališča in obrambni jarki, utrdbe, kaverne, cerkve, kapele, znamenja ter številni grajeni javni spomeniki so postali ključni del te »adaptacije «. Ponekod so spomine na vojno ohranjali s postavljanjem spomenikov s skulpturami (Dovje, Žale-Ljubljana, Šmartno ob Paki, Stara Loka, Trebnje, Žiri), spominskimi ploščami in različnimi arhitekturno-kompozicijskimi objekti (Vintarovci, Ormož, Ptuj, v tematsko zasnovane spominske parke (Dornava, 1924, 2013)) ali v novejšem času s preurejanjem nekaterih znamenj v kompozicijska znamenja kot spomin na vse vojne in povojno nasilje (Destrnik).

\section{Lokalizacija in evropeizacija dediščine vélike vojne}

V tem delu so pomembni različni diskurzi in prakse, ki definirajo dediščino vélike vojne tako v lokalnem kot globalnem smislu, hkrati pa ohranjajo spomin nanjo s spominskimi objekti na prostem in konstrukcijo spominske krajine. Lahko govorimo o rabi diskurzov, usmerjenih $\mathrm{v}$ različne vrste odnosov, ki jih posamezni deležniki formulirajo glede samih spomenikov, o vprašanju smisla vojne in razumevanju sedanjosti.

Danes obstajajo številne strategije ohranjanja spomina na véliko vojno, najbolj opazne med njimi se izvajajo na ravni fizične in simbolne krajine (na primer ohranjanje bojišč in ponovno vpisovanje fizičnih sledi vojne v pokrajino). Spomini na vojno se ne prenašajo več z generacije na generacijo, ampak jih posredujejo z gradnjo novih spominskih obeležij, muzejev, tematskih parkov in poti. Številni so spomeniki, postavljeni širom Evrope, med njimi velja gotovo izpostaviti projekt $\gg$ Pot miru od Alp do Jadrana «; nacionalni in čezmejni projekt v sodelovanju z Italijo, katerega namen je ustvariti mrežo različnih pomnikov na vojno (vključno z muzeji na prostem, spomeniki, javnimi in zasebnimi muzejskimi zbirkami) vzdolž soške fronte. Postavitev takšnih memorialov v družbeno krajino je zahteven projekt, ki terja prizadevanje številnih akterjev in skupin; to implicira tudi raznovrstne in različne definicije posameznih memorialov. Možno je razbrati različne, pravzaprav polifone vidike, agende in vloge, ki jih imajo obstoječi akterji in skupine v oblikovanju socialnega spomina ter ustvarjanju dediščinskih infrastruktur na prostem.

$\mathrm{Ob}$ teh $\gg$ lokalnih « in » nacionalnih « prizadevanjih ter aktivnostih pa lahko na primeru Kobariškega muzeja razbiramo tudi širši, 
komparativni okvir (re)memorializacijskih praks in »evropeizacijo « dediščine vélike vojne. Ob vprašanju, kateri so tisti vojni spomini, ki so izbrani in posredovani $\mathrm{v}$ diskurzu socialnega spomina na vojno, je mogoče reči, da so sporočila in zgodbe, pripovedovane v muzeju, lokalne, nacionalne, evropske; na nekaterih ravneh oziroma položajih pa so odvisne tudi od trenutnega naslovnika.

Ostanke bojišč ohranjajo in obnavljajo ne le za potomce tistih, katerih predniki so se bojevali in nekateri med njimi tudi umrli v vojni, temveč tudi za tiste, ki želijo razumeti, kako je vojna sploh potekala. Zagotovo pa je lahko najpomembnejši okvir in pomen muzejev na prostem ali rekonstrukcija 12. soške ofenzive na Kolovratu leta 2017, ki portretirajo ali bolje nakazujejo podobo vojne resničnosti in vojskovanja $\mathrm{v}$ utrjenih rovih, sporočilo miru in nesmisla vojne.

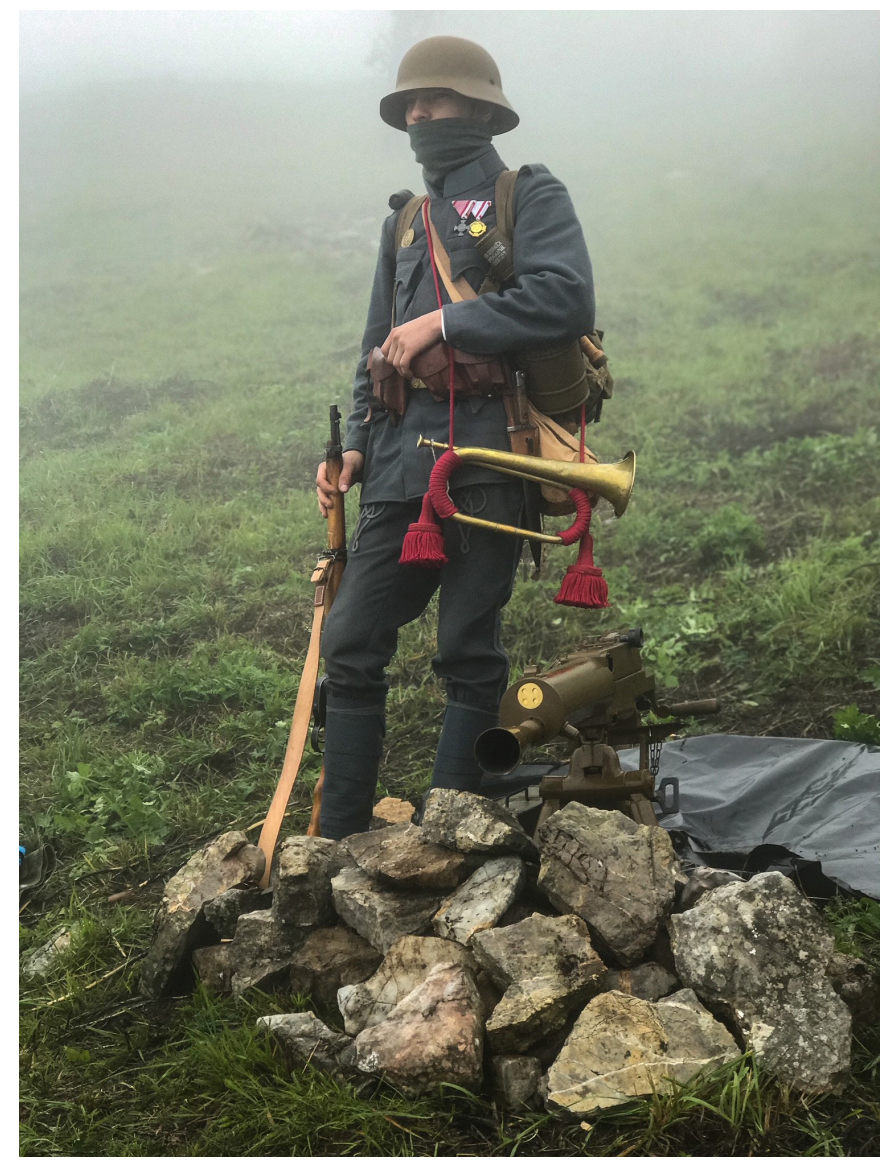

Slika 3: Avstrijski vojak. Rekonstrukcija 12. soške bitke ali čudeža pri Kobaridu (foto: Jurij Fikfak, 17. september 2017). 


\section{CITIRANE REFERENCE}

Appadurai, ArJun 2004 The Capacity to Aspire: Culture and the Terms of Recognition; V. Rao in M. Walton, ur. Culture and Public Action, str. 59-84. Palo Alto: Stanford University Press.

Baju K Senčar, TAtiana 2014 European Integration as Cultural Practice: The First Generation of Slovene Eurocrats. Založba ZRC, ZRC SAZU.

BARTUlović, AlEnKa 2012 Neskončnost povojne rekonstrukcije: Sarajevo med čakanjem in upanjem; Etnolog, str. 129-145.

2018 Representing Gavrilo Princip: Tourism, politics and alternative engagements with the memory of the Sarajevo assassination in post-war BosniaHerzegovina; Traditiones, št. 1, str. 169-191.

Baumeister, Roy F, Galit A. Dori, in Stephen Hastings 1998 Belongingness and Temporal Bracketing in Personal Accounts of Changes in Self-Esteem. Journal of Research in Personality. Letn. 32, št. 2, str. 222-235.

Bellier, IRÈne, In Thomas M. Wilson 2000 Building, imagining and experiencing Europe institutions and identities in the European Union; Irène Bellier, ur. An Anthropology of the European Union. ///

BENDER, BARBARA 1993 Introduction: Landscape - Meaning and Action: Barbara Bender, ur. Landscape: Politics and Perspectives, str. 1-17. Oxford: Berg.

Bender, Barbara, in Margot Winer, Ur. 2001 Contested Landscapes: Movement, Exile and Place. Oxford: Berg.

Bendix, Regina 2009 Heritage Between Economy and Politics: An Assessment from the Perspective of Cultural Anthropology; Laurajane Smith in Natsuko Akagawa, ur. Intangible Heritage, str. 253-269. London: Routledge.

Boissevain, Jeremy 1996 Coping with Tourists: European Reactions to Mass Tourism. New York: Berghahn Books.

Bokovoy, Melissa 2001 Scattered Graves, Ordered Cemeteries. Commemorating Serbia's Wars of National Liberation, 1912-1918; Maria Bucur in Nancy M. Wingfield, ur. Staging the Past. The Politics of Commemoration in Habsburg Central Europe, 1848 to the Present, str. 236-254. West Lafayette: Purdue University Press.

Borneman, John, IN Nick Fowler 1997 Europeanization; Annual Review of Anthropology, št. 26: str. 487-514.

CARLyON, Les 2006 The Great War. Sydney: MacMillan.

Checkel, Jeffrey T., in Peter J. Katzenstein 2009 The Politicization of European Identities; European Identity, str. 1-25.

Connerton, Paul 1989 How societies remember Cambridge: Cambridge University Press.

Feld, Steven, in Keith H. Basso 1996 Senses of Place. Santa Fe: School of American Research Press.

FIKFAK, JURIJ 2009 Cultural and social representations on the border: From disagreement to coexistence; Human Affairs, št. 4, str. 350-362. 
2014 Leaders and heroes of the nation; Traditiones, št. 1, str. 7-11.

2015 Political rituals and discourses: The case of Carinthia; Folklore, št. 60, str. 51-72.

Habinc, Mateja 2011 Folklore events: An ethnological heritage, unwanted heritage, or socialist tradition?; Southeast European (post) Modernities, str. 49-50.

HARMSEn, Robert in Thomas M. Wilson 2000 Europeanization: institution, identities and citizenship. Amsterdam: Rodopi.

Hemingway, ERnest 2014 [1929] A Farewell to Arms. With a personal foreword by Patrick Hemingway and a new introduction by Sean Hemingway. New York: Scribner.

Herzfeld, Michael 2010 Engagement, Gentrification, and the Neoliberal Hijacking of History; Current Anthropology, št. S2, str. S259-S267.

Hewison, Robert 1987 The Heritage Industry: Britain in a Climate of Decline. London: Methuen.

Hirsch, Eric, in Michael O'Hanlon, ur. 1994 The Anthropology of Landscape: Perspectives on Place and Space. Oxford: Clarendon Press

Houseman, Michael s. d. Trying to Make a Difference with »Ritual Design «. Reflexivity, Media, and Visuality. http://halshs.archives-ouvertes.fr/halshs00658668

Howard, Peter 2003 Heritage: Management, Interpretation, Identity. London, New York: Continuum.

Inglis, Kenneth S. 1987 Men, women and war memorials: Anzac Australia. Canton: American Academy of Arts and Sciences.

INGLIS, KeNNETH S., IN JAN BRAZIER 2008 Sacred places: War memorials in the Australian landscape. Carlton: Melbourne University Publishing.

Ingold, Tim 1993 The Temporality of the Landscape; World Archaeology, št. 2, str. 152-174.

2000. The Perception of the Environment: Essays on Livelihood, Dwelling and Skill. London: Routledge.

JEZERNIK, BOŽIDAR 2013 Veliki možje in razvoj slovenskega narodnega vprašanja; Božidar Jezernik, ur.. Heroji in slavne osebnosti na Slovenskem. Ljubljana: Znanstvena založba Filozofske fakultete.

2014. Mesto brez spomina: Javni spomeniki v Ljubljani. Ljubljana: Modrijan.

Kamberović, Husnija 2014 Commemoration of the First World War in Bosnia and Herzegovina; Prilozi, št. 43, str. 7-15.

KARNER, STEPHEN 2005 Die Steiermark im 20. Jahrhundert. Graz: Styria Verlag.

Kertzer, David 1988 Ritual, Politics, and Power. New Haven: Yale University Press.

Kirshenblatt-Gimblett, Barbara 2004 Intangible Heritage as Metacultural Production; Museum International, št. 1-2, str. 52-65. 
Klavora, VASja 2004 Koraki skozi meglo: Soška fronta, Kobarid, Tolmin 1915-1917. Celovec: Mohorjeva.

2007 Doberdob: Kraško bojišče: 1915-1916. Celovec: Mohorjeva.

2011 Škabrijel: Soška fronta: 1917. Celovec: Mohorjeva.

Kozorog, Mina 2012 Dante Alighieri Was Here: Place, Identities, Geographies and Histories in a Small Slovenian Town; Anthropological Journal of European Cultures, št. 1, str. 3-21.

LlOyd, DAVID W. 1998 Battlefield Tourism: Pilgrimage and the Commemoration of the Great War in Britain, Australia and Canada, 1919-1939. Oxford: Berg.

LÖFGREN, ORVAR 1989 National culture as process; Ethnologia Europaea, št. 1, str. $35-53$.

Lukes, Steven 1975 Political Ritual and Social Integration; Sociology, št.2, str. 289-308.

LytTelton, Adrian, UR. 2002 Liberal and Fascist Italy. 1900-1945. Oxford: Oxford University Press.

Maccannell, Dean 1973 Staged Authenticity: Arrangements of Social Space in Tourist Settings. Chicago: University of Chicago Press.

Manojlović Pintar, Olga 2014 Bereavement and Mourning (South East Europe); Ute Daniel, Peter Gatrell, Oliver Janz, Heather Jones, Jennifer Keene, Alan Kramer, in Bill Nasson, ur. 1914-1918-online. International Encyclopedia of the First World War. Berlin: Freie Universität. DOI: 10.15463/ ie1418.10179.

Moriarty, Catherine 1997 Private Grief and Public Remembrance: British First World War Memorials; Martin Evans in Kenneth Lunn, ur. 1997. War and Memory in the Twentieth Century, str. 125-142. Oxford: Berg.

Mosse, George L. 1990 Fallen Soldiers. Reshaping the Memory of the World Wars. New York in Oxford: Oxford University Press.

NeČAK, Dušan, In Božo RePe 2010 O feldmaršalu Svetozarju Boroeviću de Bojni. Ljubljana: Filozofska fakulteta Univerze v Ljubljani.

Newmann, John Paul 2011 Forging a United Kingdom of Serbs, Croats, and Slovenes. The legacy of the First World War and the 'invalid question'; Dejan Djokić in James Ker-Lindsay, ur. New Perspectives on Yugoslavia. Key Issues and Controversies, str. 46-61. London: Routledge.

North, Douglass C. 1991 Institutions and economic development. St. Louis: Washington University, School of Business and Center in Political Economy.

Orbaşli, Aylin, In Simon WoodWARd 2012 Tourism and heritage conservation. Thousand Oaks: The SAGE Handbook of Tourism Studies.

Povedák, István 2014 Heroes and celebrities in Central and Eastern Europe. 2014. Szeged: Department of Ethnology and Cultural Anthropology.

PrelovšEK, DAmJAN, IN VLASto Kopač 1992 Žale arhitekta Jožeta Plečnika; Damjan Prelovšek in Vlasto Kopač, ur. Plečnik, Jože, 1872-1957. Ljubljana: Mesto. 
Prost, Antoine 2014 War Losses; Ute Daniel, Peter Gatrell, Oliver Janz, Heather Jones, Jennifer Keene, Alan Kramer, in Bill Nasson, ur. 1914-1918-online. International Encyclopedia of the First World War. Berlin: Freie Universität. DOI: 10.15463/ie1418.10271.

Richards, Greg, in Julie Wilson 2007 Tourism, Creativity and Development. London: Routledge.

Rihtman-Auguštin, DunJa 2002 Etnologija i etnomit. Zagreb: ABS95.

SAUNDERS, Nicholas J. 2001 Matter and Memory in the Landscapes of Conflict: The Western Front 1914-1999. Barbara Bender in Margot Winer, ur. Contested Landscapes: Movement, Exile and Place, str. 37-53. Oxford: Berg.

SCATES, BRUCE 2006 Return to Gallipoli: Walking the Battlefields of the Great War. Cambridge: Cambridge University Press.

SCHINDLER, John R. 2001 Isonzo: The Forgotten Sacrifice of the Great War. Westport in London: Praeger Publishers.

Scott, Julie, in Tom Selwyn 2011 Thinking Through Tourism. Oxford: Berg.

SELWYN, ToM 1995 Landscapes of Liberation and Imprisonment: Towards an Anthropology of the Israeli Landscape; Eric Hirsch in Michael O'Hanlon, ur. The Anthropology of Landscape: Perspectives on Place and Space, str. 114-134. Oxford: Oxford University Press.

2004. Zapiski o vzdušju s terena: Razmišljanja o poteh mitoiskateljstva; Monitor ZSA, št. 3-4), str. 50-63.

SENJKović, ReANA 2002 Lica društva, likovi države. Zagreb: Institut za etnologiju i folkloristiku.

Silverman, Helaine, in D. Fairchild Ruggles 2007 Cultural Heritage and $\mathrm{Hu}$ man Rights. Print.

SIMČIČ, Miro 2011 Svetozar Borojević: med slavo in ponižanjem. Koper: Intelektualne storitve. 2011.

Simonič, Peter 2009 Kaj si bo narod mislil? Ritual slovenske državnosti. Ljubljana: Znanstvena založba Filozofske fakultete.

2018. Social and Cultural Relocations of Rudolf Maister: About the Political Mythology of Lower Styria. Traditiones: zbornik Inštituta za slovensko narodopisje. Letn. 47, št. 1., 193-212.

StANIfORTh, SARAH 2013 Historical perspectives on preventive conservation. Los Angeles: Getty Conservation Institute.

STANONIK, MARIJA 2007 Slovenski poskusi sintetičnih predstavitev slovenske oziroma slovanske mitologije: ob knjigi Mitološko izročilo Slovencev; Traditiones, št. 1, str. 183-190.

SvoljŠak, Petra 2011 Slovenski spomin na prvo svetovno vojno in mesto feldmaršala Svetozarja Borojevića pl. Bojne v njem; Marino Manin, ur. Feldmaršal Svetozar barun Borojević od Bojne (1856.-1920.). Zbornik radova, str. 31-42. Zagreb: Hrvatski institut za povijest. 
2018. Centenary (Slovenia); Ute Daniel, Peter Gatrell, Oliver Janz, Heather Jones, Jennifer Keene, Alan Kramer in Bill Nasson, ur. 1914-1918-online. International Encyclopedia of the First World War. Berlin: Freie Universität. DOI: $10.15463 /$ ie1418.11301.

Szczepanowska, Hanna M 2013 Conservation of Cultural Heritage: Key Principles and Approaches. London: Routledge.

ŠARENAC, DANilo 2014 Commemoration, Cult of the Fallen (South East Europe); Ute Daniel, Peter Gatrell, Oliver Janz, Heather Jones, Jennifer Keene, Alan Kramer in Bill Nasson, ur. 1914-1918-online. International Encyclopedia of the First World War. Berlin: Freie Universität. DOI: 10.15463/ie1418.10070.

Šmitek, Zmago 1998 Kristalna Gora: Mitološko izročilo Slovencev. Ljubljana: Forma 7.

ŠTEPEC, MARKo 2018 The Experience and Memory of Trenches Near the Soča River. Folklore: Electronic Journal of Folklore, št. 73, str. 19-26. https://doi. org/10.7592/ FEJF2018.73.stepec

Tilley, Christopher 1994 A phenomenology of Landscape: Places, Paths and Monuments. Oxford: Berg.

Timothy, Dallen J. 2020 Cultural Heritage and Tourism: An Introduction. Blue Ridge Summit.

Velikonja, Mitja 2018 Contested Heroes - Gavrilo Princip and Rudolf Maister as Subcultural Icons; Traditiones, št. 1, str. 213-229.

Walsh, Kevin 1992 The Representation of the Past: Museums and Heritage in the Postmodern World. London: Routledge.

Winter, CARoline 2009 Tourism, Social Memory and the Great War; Annals of Tourism Research, št. 4, str. 607-626.

WINTER, JAY 1995. Sites of memory, sites of mourning. The Great War in European cultural history. Cambridge: Cambridge University Press.

2006. Remembering War. The Great War between Memory and History in the Twentieth Century. New Haven in London: Yale University Press.

Zournazi, MARY 2003 Hope: New Philosophies for Change. Oxfordshire: Routledge. 